\title{
Fear Appeals in Social Marketing: Strategic and Ethical Reasons for Concern
}

\author{
Gerard Hastings and Martine Stead \\ University of Stirling \& Open University \\ John Webb \\ University of Strathclyde
}

\begin{abstract}
This article criticizes the predominant use of fear appeals in social marketing. Laboratory studies, which have been the basis for most of the research on fear appeals and which generally suggest that high fear works, have limitations that include forced exposure, short-term measurement, and an overdependence on student samples. Although, unfortunately, field research evaluations of fear appeals are few, they usually reveal that fear has both weaker effects and unintended deleterious effects in real-world social marketing campaigns. Ethical concerns about fear appeals include maladaptive responses such as chronic heightened anxiety among those most at risk and, paradoxically, complacency among those not directly targeted, and increased social inequity between those who respond to fear campaigns, who tend to be better off, and those who do not, who tend to be the less educated and poorer members of society. Alternatives to fear appeals are the use of positive reinforcement appeals aimed at the good behavior, the use of humor, and, for younger audiences, the use of postmodern irony. (C) 2004 Wiley Periodicals, Inc.
\end{abstract}

Fear appeals are once again popular in health campaigns and in advertising by charity organizations. Recent campaigns aimed at smoking prevention in the United States (Biener, McCallum-Keller, \& Nyman, 2000; 
DeJong \& Hoffman, 2000; Goldman \& Glantz, 1998), the United Kingdom (Baker, 1995; Grey, Owen, \& Bolling, 2000), and Australia (Chapman, 1999) have used fear-arousing images, as have campaigns for road safety in New Zealand (Land Transport Safety Authority, 2001) and in Victoria, Australia (Transport Accident Commission, 2002), and numerous charitable causes in Britain (Batty, 2001; BBC News Online, 1998). Fear appeals are embraced with enthusiasm by social marketers. For instance, the recent antismoking campaign in Australia, which has also been employed in Poland, Thailand, and Norway, was described by its producers as the "mother of all scare campaigns" (Hill, Chapman, \& Donovan, 1998).

However, the research literature on fear appeals, which consists mainly of short-term studies with students in laboratory settings, leaves a number of important questions unanswered. Are fear appeals effective in the long run? How effective are fear messages in the real world? How do fear appeals reflect on the sponsoring "brand"? What ethical issues should be considered, such as the unintended effect of fear appeals? This article attempts to answer these questions.

\section{LABORATORY RESEARCH ON FEAR APPEALS}

A large body of research over several decades has grappled with how and whether fear can persuade consumers to change their health behaviors. Different models have been proposed to describe the cognitive and emotional processes involved. These include the curvilinear model (Janis, 1967; Quinn, Meenaghan, \& Brannick, 1992), which posits that fear can persuade up to a certain threshold of tolerance, beyond which it becomes counterproductive; the parallel-response model (Leventhal, 1970), which proposes that emotional and cognitive factors act independently to mediate behavior, with emotional factors affecting internal attempts to cope with the threat (e.g., by rationalizing or rejecting it) whereas cognitive factors determine whether the recommended behavior change will be enacted; and the expectancy-valence model (Rogers, 1983), which asserts that the effectiveness of fear-arousing communications is a function of four variablesthe perceived severity of the threat, the perceived probability of its occurrence, the perceived efficacy of the advocated protective response, and the perceived self-efficacy to perform the response. This is a cognitive model in which, interestingly, the emotion of fear plays no direct role but functions only indirectly in magnifying the perceived severity of the threat. Rogers (1983) went on to argue that his four variables interact and produce, in the individual, a level of "protection motivation" that determines the degree of change in the recommended behavior.

Many studies have investigated the relationship between the amount of fear evoked and the resulting attitude change or behavior change. Some have found a linear association-the more fear, the more effect 
(e.g., Baron, Logan, Lilly, Inman, \& Brennan, 1994; Boster \& Mongeau, 1984; Higbee, 1969; LaTour \& Pitts, 1989; Millar \& Miller, 1998; Rotfeld, 1988). Others suggest that, as too much fear can result in dysfunctional anxiety, moderate levels of fear perform better, producing an inverted-Ushaped model (e.g., P. A. Keller, 1999; Krisher, Darley, \& Darley, 1973; Quinn et al., 1992). However, the most recent meta-analysis concluded that the preponderance of evidence supports a linear model of fear arousal-the more fear, the greater persuasion-and that there is no evidence to support the inverted-U-shaped model of fear (Witte \& Allen, 2000). Several studies indicate that self-efficacy, the perceived ability to make the behavior change advocated in the message, moderates the effect of fear on attitude and behavior change (Anderson, 2000; Girandola, 2000; Ruiter, Abraham, \& Kok, 2001; S. L. Smith, 1997; Snipes, LaTour, \& Bliss, 1999).

The research literature, then, would seem to support the current practice of using high levels of fear in social advertising. High fear should be the most effective, providing that the proposed coping response to the threat is feasible and within the consumer's ability (Blumberg, 2000; de Turck, Goldhaber, Richetto, \& Young, 1992; Donovan, 1991; Snipes et al., 1999; Witte, Berkowitz, Cameron, \& McKeon, 1998).

However, there are many questions about laboratory research on fear appeals. For marketers, the crucial question is not "can fear messages change behavior in the laboratory" but, rather, "can fear appeals change behavior in the sophisticated and overcrowded clutter of the real-world communications environment?" Existing research struggles to provide an answer for several reasons: First, most studies have been conducted in artificial environments; second, the definitions of fear used are sometimes unclear and the measures of effects are limited; third, narrow or inappropriate samples have often been used; and fourth, there are few publicly available studies that have examined real advertising campaigns that use fear appeals. These reasons are elaborated below.

\section{Artificially High Attention}

Fear research has been concerned more with internal rather than external validity (Alwitt, 2002). The literature is dominated by laboratory studies that put respondents into artificial situations that are unlikely to capture phenomena that occur in a naturalistic setting (e.g., the "This is a market research study ..." instruction used by P. A. Keller \& Block, 1996). In ordinary TV viewing conditions, people can choose to zip through or zap out the ads they do not like (Kitchen, 1986), and they can selectively attend to ads that support their prevailing attitudes and behaviors, to minimize dissonance and preserve self-esteem (Pechmann, 2001). Fear research studies in the laboratory, however, typically involve carefully selected respondents who are instructed to pay attention to a specific ad or message shown in a laboratory environment (e.g., de Turck, 
Rachlin, \& Young, 1994; P. A. Keller \& Block, 1996; Menasco \& Baron, 1982; Moore \& Harris, 1996; Schoenbachler \& Whittler, 1996). Selecting and directing respondents in this way reveals little about how a realworld audience might respond spontaneously to a particular communication, or about whether the communication is able to compete well with others for attention in the duration of an actual commercial break or in the pages of a print medium (Chaudhuri, 1996). The laboratory circumstances are also likely to encourage cognitive, rational processing, whereas unconstrained viewing more often produces heuristic or affective processing (Brown, Homer, \& Inman, 1998). Furthermore, asking consumers to explain their responses to advertising may not yield accurate answers, because consumers tend to revert to the safety of logical explanations for what are largely emotion-based reactions (Hackley \& Kitchen, 1999; Weirtz, 1998).

\section{Unclear Definitions and Limited Measures}

The fear literature suffers from a tendency to conflate the concepts of fear, which is a response, and threat, which is a stimulus (Donovan \& Henley, 1997; LaTour \& Rotfeld, 1997). There is widespread failure to specify how stimulus materials may arouse fear, and a lack of clarity about what high, moderate, and low levels of threat really are (Moore \& Harris, 1996; Tanner, Hunt, \& Eppright, 1991). Many studies, too, employ weak, or at least limited, measures of effectiveness. For example, several are based on perceived effectiveness rather than observed effects; consumers are simply asked how effective they believe a particular fear message to be (e.g., Biener \& Taylor, 2002; Biener et al., 2000). Self-reported effectiveness is problematic because it does not correlate well with actual behavior (Austin, Pinkleton, \& Fujioka, 1999). Respondents frequently state in research that strong fear appeals are highly motivating, and state their intentions to change, even when subsequent research shows that these appeals do not change their behavior (DeJong \& Wallack, 1999). Audiences are quite capable of recognizing, and describing with some sophistication, what they understand an advertiser to be trying to achieve, without necessarily being personally moved. Young people are simultaneously able to recognize that a drugprevention ad or smoking ad is "trying to scare us into not taking drugs or not smoking," and to find it personally irrelevant (Cohn, 1998; Hastings \& MacFadyen, 2002). In a number of research projects conducted to help develop HIV/AIDS campaigns in the 1990s, Scottish teenagers recognized that the advertising was intended to frighten "people in general" or "others," but they did not identify with it: Shock approaches, they felt, would work for others but not for "me" (Hastings, Eadie, \& Scott, 1990); similarly, smokers can describe a hard-hitting ad as good while claiming that it fails to scare them personally (MacAskill, Will, Hughes, \& Eadie, 1993). 


\section{Narrow or Inappropriate Samples}

Much of the research on fear appeals has been conducted with students, typically psychology or marketing students (e.g., G. E. Belch, Belch, \& Jones, 1995; de Turck et al., 1994; Johar \& Segal, 1987; P. A. Keller, 1999; P. A. Keller \& Block, 1996; Menasco \& Baron, 1982; Tanner et al., 1991; Witte et al., 1998). Conclusions drawn from studies of this relatively homogeneous group of highly educated young adults may not apply to other groups of the population, such as the less educated, adolescents, older people who are chronically ill, and members of non-White ethnic groups. These groups are often the targets of fear messages (Chaudhuri, 1996).

Several studies and communications experts have suggested that fear appeals are likely to work differently with adults compared with young people (e.g., Backer et al., 1992; Belch et al., 1995; Hale \& Dillard, 1995; Health Education Board of Scotland [HEBS], 2002); indeed, some suggest that fear campaigns will be ineffective or counterproductive with young people because teenagers and young adults have little sense of their own mortality (Pechmann, 2001) and may indeed regard threatening messages as a challenge (Backer et al., 1992; Brody, 1998; PBS Newshour, 1999). Fear appeals may also work differently in different countries. What is experienced as persuasive and acceptable in one culture may resonate less well with, or be seen as unacceptable in, another culture (Laroche, Toffoli, Zhang, \& Pons, 2001; Williams, Briley, Grier, \& Henderson, 1998). This is not just an East-West divide, because there are differences between Western countries, too: Whereas there is a tradition of hard-hitting, threat-based public-health and road-safety advertising in some Western countries, such as the United States and Australia, others, such as The Netherlands and Canada, have for many years favored supportive, empathy-based advertising (see, e.g., Cotroneo \& Schoales, 1999; Stivoro, 1998; Tripp \& Davenport, 1988/89). These differences regarding the use of fear are likely to reflect, at least in part, national differences in beliefs about what is politically, culturally, and philosophically appropriate for public-sector advertising, and not necessarily which approach is most effective.

\section{Few Real Intervention Studies}

Only a few studies reported in the public domain have evaluated fearbased advertising in real-world interventions. Examples are evaluations of some smoking cessation campaigns in the United States, United Kingdom, and Australia, and recent road-safety campaigns in Australia. Findings from these studies suggest that, leaving aside the difficulties of disentangling advertising effects from other effects in nonexperimental or quasi-experimental studies (Macpherson \& Lewis, 1998; Transport Accident Commission, 2002), fear-arousing campaigns usually are effective in raising awareness and changing attitudes (Biener et al., 2000; Donovan, Jalleh, \& Henley, 1999; Grey et al., 2000; Hill et al., 1998) but only 
some campaigns show an improvement in the targeted behavior (Baker, 1995; Transport Accident Commission, 2002).

Also, like the laboratory studies, the real-world studies tell us little about the sustainability of the effects, or the effects they may have on wider marketing concerns such as branding and relationship building, or whether messages not based on fear might work better. These issues are discussed next.

\section{LONG-TERM EFFECTS OF FEAR CAMPAIGNS}

The laboratory studies reviewed above reveal nothing about the longterm effectiveness of fear campaigns. And even when naturalistic studies show some influence on behavior, measurement is rarely continued beyond the short term (Pierce, Macaskill, \& Hill, 1998).

Nor does the literature tell us anything about the effects of long-term exposure to repeated fear messages. First, it is unlikely that response to a repeated fear ad remains static-it is more likely that attitudes are formed, re-evaluated, and updated in a dynamic process over the duration of a campaign (Japerson \& Fan, 2002). For example, a drug-prevention ad that seems initially shocking to an individual young person might, after prolonged exposure and the opportunity to discuss the ad with his or her peers, become predictable, boring, or even laughable (e.g., Cohn, 1998; Hastings \& MacFadyen, 2002). These dynamic changes in response could not be predicted by a single-exposure laboratory study of a fear ad, or by the one-time evaluation of a fear-based campaign.

Repetition of shock ads is a case in point. Shock ads are undoubtedly effective in commanding attention initially (Weinreich, 1999), but after numerous screenings they may simply stop working (e.g., Fry, 1996). Schoenbachler and Whittler (1996) suggest that any fear appeal that employs a physical threat will be effective in the short term at triggering appropriate behavioral intentions, but that, with repetition, its influence will diminish. It is possible that a law of diminishing returns (Beauchamp \& Bowie, 1988) operates with high-threat advertising whereby there is a need to intensify the threat on each subsequent occasion to produce the same level of fear.

Second, repetition may lead to habituation, annoyance, and an increased tendency for individuals to tune out the message. Fear research studies tend to assume that consumers come to each new fear message cold, neglecting the fact that many will already have been exposed to such messages before and will have developed well-learned defensive avoidance strategies (Tanner et al., 1991). Ongoing research into smokers' reactions to current U.K. and proposed new European Union warnings on cigarette packs indicates that smokers become inured to pack warnings over time and are adept at screening them out (Devlin, Eadie, Hastings, \& Anderson, 2002). Similarly, Coulter, Cotte, and Moore (1999) 
suggest that viewers draw on their knowledge of previous advertising, and that once they become aware of an advertising tactic as a tactic, it experiences a change of meaning and has less power to persuade them.

Third, repeated use of fear strategies for particular issues may condition audiences to expect that all advertising on that topic should use fear. For example, smokers in qualitative pretesting research will frequently state that antismoking ads should use visuals of blackened lungs, and drivers in ad pretests will demand that antispeeding ads show pedestrians being bounced off car bonnets (e.g., Eadie \& Stead, 1998; Stead \& Eadie, 2000). When consumers are presented with an ad that does not fit into these genre expectations-a road safety ad that deliberately avoids showing a gory accident and instead uses a low-key empathy approach, for example-their initial response is to reject the ad (Eadie \& Stead, 1998). If campaign planners take these qualitative responses at face value, new approaches to road-safety advertising may never get off the drawing board, despite their potential effectiveness. In Exhibit 1 is a case summary of an antispeeding ad campaign that braved departure from the conventional fear-appeal approach.

Fourth, long-term use of fear messages may damage the source of the message; the source (the sponsor) could become irretrievably linked with the negative and the threatening. In the commercial sector this concern typically becomes focused on the brand.

\section{THE EFFECT OF FEAR CAMPAIGNS ON THE "BRAND”}

The brand equity of successful commercial products like Coca-Cola and McDonald's has taken many years of careful planning and investment. As a consequence, commercial marketers are cautious about how they use and portray their brands, and do not allow them to be placed in inappropriately themed ads, of which fear appeals may be an example. It is reported that neither of these companies will advertise in or near the evening TV news due to concerns over shocking news reports and the tendency of news broadcasts to dwell on the negative.

There is much debate about the transferability of branding, in all its complexity, to a social marketing setting (Belinoff, 1995; K. L. Keller, 1998). However, in terms of message source effects, this thinking is not contentious: The body that produces the communication-the social brand-will have both an image and a reputation (probably with several publics) and these are likely to be affected by the type of message it transmits. However, little actual research has examined how the use of fear appeals affects the reputations of marketers operating in the health and safety domains. What evidence there is suggests a need for caution. Studies of political advertising have found that using negative information tends to reflect badly on the political party that sponsors the ad (Japerson \& Fan, 2002; Meirick, 2002; Pinkleton, Um, \& Austin, 2002). Also, the 
Foolsspeed was a 5-year campaign by the Scottish Road Safety Campaign to reduce speeding in urban areas. The main element of the campaign was a 3-year (1999-2001) mass-media advertising campaign underpinned by the theory of planned behavior, or TPB (Ajzen, 1988). Three television ads were developed, each targeting one component of the TPB (attitudes, subjective norms, and perceived behavioral control), and broadcast over 3 years, one ad per year. The ads deliberately avoided fear; instead, humor and credible driving scenarios were used to increase driver identification and empathy. Despite initial reactions in the qualitative development research that the storyboards were too tame, drivers related reasonably well to the low-key approach (Eadie \& Stead, 1998). For example, many were able to identify with the characters depicted in the ads, and they also acknowledged that gory accidents are rare in day-to-day driving (Stead \& Eadie, 2001).

The advertising campaign was evaluated in a 3-year longitudinal survey of overlapping quota samples of drivers ages $17-54$ years ( $n=550$ per sample). The survey measured awareness and recall of elements of the Foolsspeed campaign, examined response to the specific Foolsspeed ads in terms of comprehension, identification, involvement, and perceptions of key messages, and measured and compared drivers' attitudes, subjective norms, perceived behavioral control, intentions, and reported behavior in relation to urban speeding (exceeding the 30 m.p.h. speed limit on urban roads in Scotland) at baseline and at subsequent stages to assess whether any changes occurred. A baseline survey was conducted in October 1998, and follow-up surveys were conducted in Spring 1999, Spring 2000, and Summer 2001, approximately 4-6 weeks after the media burst for each ad.

The Foolsspeed campaign achieved high spontaneous and prompted ad awareness levels throughout its duration, and the individual ads were easily understood and perceived not to be patronizing. Drivers identified with the ads (and speeding drivers identified with them to a greater extent than nonspeeding drivers) and indicated that the ads had made them reflect on their own driving and how it was perceived by others. These results suggest that it is possible to create memorable and engaging road safety advertising without using fear. Detailed analysis of the TPB measures suggested that the campaign was associated with significant changes, in an antispeeding direction, in attitudes toward speeding and in positive and negative affective beliefs (beliefs about the emotional benefits connected with speeding), as well as self-reported speeding behavior (Stead \& Eadie, 2001).

use of threats that the target group finds exaggerated or that do not reflect the target group's personal beliefs and experiences can result in the target group discrediting the communicator (Tripp \& Davenport, 1988/89). Because, for example, teenagers know that most people do not die from drugs, and drivers know that most speeders do not have accidents, organizations that sponsor these messages are seen, at best, as out of touch or phony, and at worst as dishonest (Belch, Belch, \& Jones, 1995; Buchanan \& Wallack, 1998). Focusing on particular threats while appearing to neglect others more salient to the target group opens the communicator to a charge of hypocrisy; for example, young people may respond to hard-hitting drug-prevention campaigns by pointing out that the government permits the advertising of a drug, namely, tobacco, and smokers may retort that “the government doesn't really want us to stop smoking because it 
makes money out of us," or "look at all the doctors who smoke" (Devlin, Eadie, Hastings, \& Anderson, 2002; Tripp \& Davenport, 1988/89). An unexplored research question is whether campaigns based on nonfear appeals (for example, campaigns that portray positive images of people who state that they do not use drugs, or campaigns providing reassurance for those who quit drugs) trigger similar negative feelings about the source and provoke similar accusations of hypocrisy.

Some research has suggested a relationship between enjoyment of an ad and a favorable attitude toward the brand (Belch \& Belch, 2001; Biel, 1998; Pelsmacker \& Geuens, 1999), and that dislike of an ad (because, say, it uses unpleasant images or makes one feel uncomfortable) can translate into an unfavorable attitude toward the brand, although this has been disputed as a general finding (LaTour, Snipes, \& Bliss, 1996; Rossiter \& Eagleson, 1994). It is also possible that the use of highly dramatic advertising may hinder brand recognition (Alwitt, 2002). On the other hand, using an attention-grabbing threat might assist brand recognition if it helps an ad fight through clutter (Moore \& Harris, 1996). All these possible effects of the use of fear on brands need further research.

Even less research has looked at the long-term implications of fear appeals for the development of a brand's strategic purpose. For commercial marketers, all their advertising and other marketing activities must resonate with and bolster the "brand essence" (de Chernatony, 2001). Advertising propositions must be consistent with the brand image; otherwise the brand can be damaged (e.g., advertising that continually mentions price or promotion offers may damage a brand positioned as a luxury; see de Chernatony, 2001). Charitable organizations have to be particularly mindful of their reputations when using fear and other negative tactics (Moore \& Hoenig, 1989). For example, in recent years several major U.K. charities such as Barnardo's, the NSPCC (National Society for the Prevention of Cruelty to Children), the Commission for Racial Equality, and the RSPCA (Royal Society for the Prevention of Cruelty to Animals) have run the risk of harming their brand images with campaigns that employ deliberately shocking messages (Batty, 2001). Although consumers may be less likely to complain about ads by charities because they impute basically honest and ethical motives to them (Coulter et al., 1999), advertising experts caution that charities should not assume they have carte blanche to push the limits of acceptability (BBC News Online, 2000).

Some social marketers do pay close strategic attention to their brands. HEBS, which, in a mass-media advertising campaign in the 1990s targeted at young people used positive and humorous message approaches to promote informed decision-making regarding smoking, drinking, drug use, and sexual health, was concerned about how the subbrand of the campaign, "Think about it," and the overall brand, HEBS, fit together in consumers' minds. In particular, did the HEBS branding, which might be seen by young people as the establishment, hinder the image of the 
"Think about it" campaign? Research prior to the campaign (HEBS, 2001) indicated that HEBS had a good brand image among young people and that the branding was appropriate, and HEBS needed this confidence to proceed with the campaign. For campaigns that employ fear, there is a particular need to investigate both how the brand (the source) influences the fear message, and how the fear message, especially if prolonged, plays back on the brand.

\section{CUSTOMER AND STAKEHOLDER RELATIONSHIPS}

Marketing success is increasingly being seen as a process of building long-term relationships with customers (Grönroos, 1994, 1995) and other stakeholders (Morgan \& Hunt, 1994). These ideas emerged initially from the services and business-to-business sectors where customer relationship management (CRM) had assumed great importance. Subsequently, advances in information technology have led to the development of $e$ CRM (O'Driscoll \& Murray, 1998) and the transfer of the CRM approach into the fast-moving consumer goods (FMCG) sector. The benefits of CRM are supposed to be better long-term planning because the company gets to know its customers; lower price sensitivity because service quality and trust provide valued compensations; and more opportunities to sell related products (O'Malley \& Tynan, 2000). Although the viability of the relational metaphor has been questioned (e.g., O’Malley, 1998; Tynan, 1997; Tzokas \& Saren, 1997), a recent survey conducted by the Economist Intelligence Unit (EIU) revealed that customer satisfaction has now become the principal global indicator of managers' performance (Richardson, 2001). More recently, relational ideas have been applied to social marketing (Hastings, 2003).

\section{Relationships with Customers}

The importance of customer relationships is well established in commercial marketing. Loyal customers are remarkably valuable to a company (Doyle, 1989, 1997). They buy more of its products, are easier to satisfy, are less price sensitive, and make positive recommendations to their friends and family. Furthermore, acquiring new customers through sales calls, advertising, and promotions is reportedly five or six times more expensive than retaining existing ones (Knauer, 1992). Similarly, research indicates that the average company loses $10 \%$ of its customers each year, and if this could be reduced to $5 \%$, profitability would be increased by $25 \%$ or more (Reicheld \& Sasser, 1990). In contrast, unhappy customers are a liability - they tend to stop buying the company's products without warning, to support the competition, and to complain to their friends and family (Goodman, 1995). A further benefit of establishing relationships with loyal customers is that there are opportunities 
to gain ongoing useful feedback on performance that makes for product and service improvements (Weir \& Hibbert, 2000). Consensus has therefore emerged in the business world that commercial success is built not on one-off sales but on long-term relationships between the marketer and the customer: so-called relationship marketing. The essence of relationship marketing is the individual-level relationship with the customer. This means gathering detailed information about the consumer; using this to tailor future communications and service interactions to the individual's needs (Barton, 1999; Weir \& Hibbert, 2000); and offering these communications at times when consumers need or want them, rather than at times when consumers are likely to be irritated or apathetic (Bolling, 2001). Key elements in a successful marketer-customer relationship are trust, loyalty, two-way communication, and honest communication (Morgan \& Hunt, 1994; Treasure, 2002).

There appears to be no research that examines the use of fear in marketing communications from the perspective of relationship marketing, but a number of inferences from CRM can be posited as research questions. If consumers' feelings of self-esteem and personal comfort are threatened by fear messages, are they likely to be receptive to building a long-term relationship with the communicator? Are they less likely to want to provide information about themselves? What sort of relationship is engendered as a result of fear appeals: one of mutual respect between adults, or a more patronizing, parent-child one (Lannon \& Cooper, 1983)? If the latter, how durable is this type of relationship?

\section{Relationships with Stakeholders}

Communications with stakeholders typically do not involve the mass media, and would not usually resort to threats. Rather, the emphasis is on shared objectives and mutual respect. Nonetheless, fear messages are an important issue here, as messages directed at customers are frequently picked up by other stakeholder groups. This can be problematic. Charities' fear-arousing advertising targeted at potential donors often has to portray the beneficiary group as endangered and suffering because the public demands pathos (Ramrayka, 2001); thus, for example, a children's charity "needs cruelty to children to be seen to occur because, without that, it has no raison d'etre" (Rayner, 1999). However, donor-intended messages seen by beneficiaries can cause anguish. For example, the British Multiple Sclerosis Society's 1992 campaign, "MS tears lives apart," was premised on the notion that MS has devastating effects, turning previously healthy and perfect people into damaged, infantile victimsa powerful fund-raising image, no doubt, but disempowering to sufferers coping with MS (Hevey, 1992). Similarly, a "Help the aged" poster campaign depicting eight pairs of feet in a morgue, with the tag line, "Thousands of elderly people will stop feeling the cold this winter," was criticized by a pensioners' group for being upsetting to the very group the 
campaign was intended to help (BBC News Online, 1998). More recently, an ad in a controversial campaign for Barnardo's about childhood deprivation, which depicted a young man who killed himself after being abused as a child, was strongly criticized by a mental-health charity representing parents of children who committed suicide, and was subsequently withdrawn (Batty, 2001). Fear appeals may therefore have deleterious effects on other stakeholders.

\section{ETHICAL ISSUES}

Fear appeals raise issues of ethics. Threat-based ads explicitly use the force of fear to try to manipulate human behavior. Any deliberate fostering of anxiety by marketing communications has ethical implications. As Hackley and Kitchen (1999) argue, even if we accept the picture of the sophisticated postmodern consumer who can skillfully negotiate his or her way through a bombardment of marketing communications, it is still possible that advertising may have deleterious individual and societal effects that merit ethical scrutiny. These concerns should be particularly salient to the examination of marketing communications that deliberately and explicitly use threats. Furthermore, social marketers should heed that target audiences can have doubts about the ethicality of social advertising, even when they acknowledge its good intentions (Arthur \& Quester, 2003).

Advertising practitioners, themselves, perceive potential moral problems with fear appeals. The U.K.'s ITC Code of Conduct for television advertising (see Exhibit 2) states that fear should not be used in general advertising without reasonable justification; in religious advertising; in the advertising of medicines and health-related products; and in advertising to children, particularly the fear of ridicule for not owning the latest toys or games.

Psychological perspectives add depth to these concerns. Beauchamp argues in his discussion of whether advertising diminishes free choice that "manipulative advertising" (defined as that which, among other things, exerts "emotional pressure") poses moral questions for the advertiser if it compromises the "manipulee's" ability to make a rational and free choice or exploits a particular vulnerability, for example, the vulnerability of young, ill, or addicted consumers (1988, p. 422). It has also been suggested that fear appeals are unethical because they expose audiences-unwillingly — to graphically upsetting images (discussed below).

The problem of collateral damage has also to be considered. Massmedia messages inevitably reach, and often annoy, unintended audiences who are not in the market for particular goods or behaviors (Hackley \& Kitchen, 1999; N. C. Smith \& Quelch, 1992). Hard-hitting antismoking ads depicting disease and death are as likely to be seen by the children 
Fear appeals should be avoided:

- In advertising in general (article 16: "Appeals to Fear. Advertisements must not without justifiable reason play on fear");

- In religious advertising (Appendix 5, article 9: "No advertisement may play on fear. References to alleged consequences of not being religious or not subscribing to a particular faith are not acceptable");

- In advertising of medicines and other health related products (Appendix 3, article 19): "Appeals to Fear or Exploitation of Credulity. No advertisement may cause those who see it unwarranted anxiety lest they are suffering or may suffer (if they do not respond to the advertiser's offer) from any disease or condition of ill health ... or that health could be affected by not taking the product").

- The Code also cautions against invoking social fear in the context of advertising and children, stating that advertising should not lead children to believe that "if they do not have or use the product or service advertised they will be inferior in some way to other children or liable to be held in contempt or ridicule" (article 7: Inferiority).

of adult smokers as by smokers themselves, with possible distressing consequences (to both children and parents). Road-safety TV ads aimed at 18-24-year-olds will also reach other drivers and may breed complacency in the many of us who are in fact at least occasional speeders by implying that deaths on the road are the fault of inexperienced and unskilled drivers. These ads could demonize the featured subgroups (e.g., young male drivers). They may cause unwarranted anxiety among pedestrians (the so-called "worried well" syndrome) and perhaps scare parents into keeping their children indoors.

Support for these concerns is provided by ethical theory. Deontological, or duty, theory, which is concerned with the inherent morality, humaneness, and intentionality of the act, would reject the use of fear appeals outright on the grounds that, regardless of the ultimate societal consequences, it is wrong to engender anxiety and distress (Duke, Pickett, \& Grove, 1993; N. C. Smith \& Quelch, 1992; Snipes et al., 1999). Teleological, or utilitarian, theory, which is concerned with the consequences of an act and holds that an action is ethical if it produces a net balance of good over bad, would support the use of fear if the product, behavior, or idea being promoted is beneficial to society and if other approaches are less effective. From a utilitarian perspective, however, fear messages can also have health-damaging consequences and these consequences appear to be most likely to occur among consumers who are already the most vulnerable and at risk, as discussed next. 


\section{Health-Damaging Consequences}

Various studies have demonstrated that exposure to fear appeals can evoke maladaptive responses-responses designed not to control or remove the danger addressed in the ad but to cope with the unpleasant feelings evoked by the fear message (e.g., Janis \& Mann, 1997; Schoenbachler \& Whittler, 1996; Tanner et al., 1991; Witte et al., 1998). These maladaptive responses include avoiding or tuning out the message, blunting (failing to process the salient threat part of the message), suppression (failing to relate the threat to oneself), and counterargumentation (summoning arguments against the message's veracity); see Blumberg (2000); Sego and Stout (1994); and P. A. Keller (1999). Maladaptive responses are inherently dangerous because they minimize the threat without minimizing the consumer's actual risk or danger (Schoenbachler \& Whittler, 1996). They may lead consumers to miss important health information (Belch et al., 1995) or to process information in a biased manner and draw erroneous conclusions about the relative risks of different health behaviors (Ruiter et al., 2001). For example, charity advertising to raise awareness of the threat of child abuse and murder, such as the NSPCC's "Full stop" campaign, may scare parents into preventing their children from walking to school-thereby exposing them to the statistically more probable risk of having an accident in a car (Rayner, 1999). There are also potentially damaging long-term consequences on children's development from campaigns that result in their play and movement opportunities being limited due to parental fear.

Smoking-prevention ads may evoke the existential dread of one's own death (Henley, 2002). Similarly, given the high levels of anxiety that already exist about diseases like cancer (e.g., Ong, Austoker, \& Brouwer, 1996; Stead, Low, \& MacFadyen (1996), one must ask whether it is ethical to generate even greater anxiety, which may not only make people uncomfortable, but reluctant or unable to seek help or diagnostic tests. The fact that advertising messages typically intrude on people's lives without permission adds to this dilemma. Fear appeals "expose a person against his or her will to harmful or seriously offensive images" (Hyman \& Tansey, 1990, p. 110) and may create unnecessary consumer anxiety (Benet, Pitts, \& LaTour, 1993; LaTour \& Zahra, 1989). Henthorne, LaTour, and Nataraajan (1993) argue that individuals targeted by fear messages ". . . should not be subject to the psychological discomfort of excessive tension, generated for the purpose of motivating a desired behavioral outcome. Rather, fear appeal stimuli should be tested to ensure that a given stimulus results primarily in energy generation rather than tension" (p. 67). In other words, any level of fear that is not "psychologically "comfortable" may be unethical (Henthorne et al., 1993).

One way of coping with an unpleasant fear message is to deny its personal relevance (e.g., Hastings, Eadie, \& Scott, 1990; Hastings, Leather, $\&$ Scott, 1987). Constant exposure to fear messages may encourage in 
some individuals feelings of invulnerability (Schoenbachler \& Whittler, 1996): "it might happen to others but not to me." It was to avoid this response that the Foolsspeed campaign (Exhibit 1 earlier) depicted ordinary, realistic consequences of speeding, such as feeling foolish and not feeling fully in control.

Another harmful response to constant exposure to fear-inducing messages may be to encourage or reinforce health fatalism, a common response in research with consumers about smoking, illicit drug-taking, and road safety (e.g., Henley, 2002; Stead et al., 1996). Fatalism reinforces low self-efficacy- "there's nothing I can do about the threat anyway"-thereby rendering the fear message counterproductive (Rippetoe \& Rogers, 1987).

Furthermore, the anxiety and discomfort experienced when watching or listening to a fear message may trigger the very behavior that the ad is designed to prevent (Henley, 2002). For instance, it is not unusual for smokers to say in qualitative advertising pretests and post-tests that a hard-hitting smoking ad makes them feel so bad that they have to have a smoke (Eadie \& Smith, 1995; MacAskill et al., 1993; Tripp \& Davenport, 1988/89). Mayne (1999) suggests that intense anxiety may lead individuals to engage in risky behaviors such as drug use, alcohol abuse, and overeating as coping mechanisms to (temporarily) relieve the negative emotion. There is also the perverse possibility that the arousal stimulated by fear appeals exacerbates the dangerous behavior. For instance, a domestic-violence advertising campaign in Scotland using fear-arousing and shocking imagery was discovered, in qualitative posttesting after the campaign, to have actually triggered attacks from violent partners (MacAskill \& Eadie, 1995).

\section{More Health-Damaging Consequences among the Most Vulnerable}

Several studies have found that fear-arousing messages work when consumers have high self-efficacy (given that they perceive high response efficacy), and do not work, or work less well, when consumers have low selfefficacy (e.g., Blumberg, 2000; de Turck, Goldhaber et al., 1992; Donovan, 1991; Snipes et al., 1999; Witte et al., 1998). In other words, fear-arousing campaigns are most persuasive with those segments of the target population who are (already) the best equipped, psychologically and socially, to act on and benefit from the persuasive message. On the other hand, they make psychologically and socially less-resourced individuals feel worse, by inducing feelings of anger and defensiveness, and encouraging maladaptive responses that further increase these people's risk and vulnerability. People who chronically engage in health-damaging behaviors such as smoking and illicit drug use typically have lower selfefficacy than those who do not (Botvin, Malgady, Griffin, Scheier, \& Epstein, 1998; Conrad, Flay, \& Hill, 1992; Elders, Perry, Eriksen, \& Giovino, 1994; Johnson et al., 1990). 
Fear-arousing campaigns may therefore cause both absolute harmby causing further distress to the most vulnerable in the population and rendering them (less) able to act on health advice-and also relative harm, by being disproportionately effective with population segments who are already high in the resources needed to make the recommended changes in behavior, thereby causing the less efficacious to lag even further behind (Arblaster, 1996; Hastings, Stead et al., 1998). The inequality violates, in ethical theory, the principle of equal justice for all. Indeed, Witte et al. (1998, p. 584) argue that if a public health campaign cannot adequately work with consumers who are low in efficacy as well as with consumers who are high in efficacy, "then practitioners should avoid the use of fear appeals in that campaign."

\section{ALTERNATIVES TO FEAR APPEALS}

Fear appeals draw their power from their ability to engender strong negative emotions, primary among them, of course, fear. However, appeals based on positive emotions-love, excitement, sex, hope, and humormight be equally effective. An appeal based on hope, by The Salvation Army in Australia, is exemplified in a newspaper ad (The Australian, July 4, 2003, p. 15) shown in Figure 1. The campaign was also run on TV. The sponsor reported in private that this campaign has been very effective in encouraging donations.

The key question becomes not "should fear appeals be used?" but "will fear appeals do the job more or less successfully than alternative approaches?" (Menasco \& Baron, 1982; Monahan, 1995). Political advertising research suggests that whereas fear appeals may work with some segments of the electorate, reward appeals may work better with others, such as people who are less authoritarian, and indeed that some products that are advertised primarily using fear appeals may be handicapping themselves by failing to reach out to all segments of the market (Wan, Meirick, Williams, Holmes, \& Feibich, 2000). In a similar vein, some charities are turning away from hard-hitting tactics, believing that in the long run these turn people off, and instead are opting for humorous approaches (Batty, 2001).

Attention has recently turned in road-safety advertising to the potential value of "empathy strategies" (Slater, 1999), which have been used to promising effect in a recent theory-based mass media antispeeding campaign in Scotland (see Exhibit 1).

Recent antismoking and antidrug media campaigns have employed humor, irony, and supportive messages, which have produced favorable results in terms of awareness, liking, attitude change, and attempts to quit (e.g., Belch et al.,1995; Bureau NDM, 2001; HEBS, 2001; Pechmann 2001; Schoales, Mintz, \& Hazel,1999). In the Massachusetts antismoking campaign, for example, noted for its use of graphic, fear-arousing 


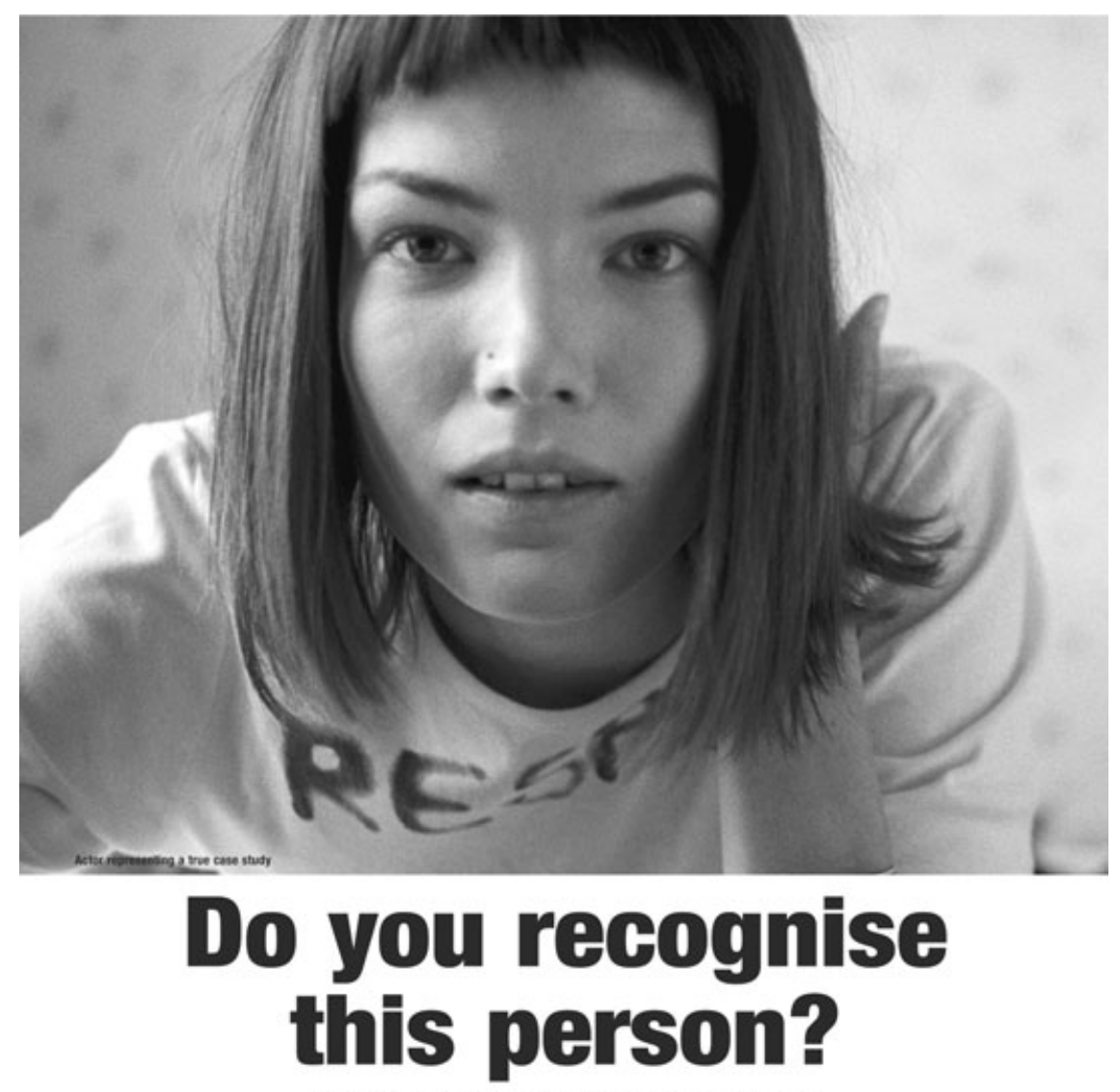

These days she can hardly recognise herself.

When Amanda wanted help to break her drug addiction, she called The Salvos. She's living proof that Treatment Works.

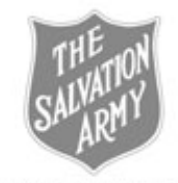

\section{TREATMENT WORKS}

If you need help for drug and alcohol addiction, call Salvo Care Line 1300363622 or visit www.salvos.org.au

Figure 1. An appeal based on hope. (Courtesy: The Salvation Army of Australia.)

images, some of the most effective ads were those emphasizing empathy, not fear (Biener \& Taylor, 2002). Other nonfear strategies effectively used in social marketing campaigns are positive role models (de Turck et al., 1994), empowerment, and even sexual appeals (Reichert, Heckler, \& Jackson, 2001). 
Another nonfear approach is postmodernism-an advertising style characterized by relativism, irony, surrealism, self-referentiality, and hedonism (Hackley \& Kitchen, 1999). Postmodern appeals do not try too hard or appear too obvious (although they may do either or both, ironically), they treat the consumer as knowing and worldly wise (for example, advertising that draws attention to the conventions of advertising itself or acknowledges the consumer's capacity for boredom and irritation), and they avoid appearing desperate (as Kirmani, 1997, p. 84, expresses it, if an ad is too insistent or repetitive, it signals "something must be wrong"). It is possible that, as consumers become more accustomed to this sort of knowing, ironic, relativist advertising, the obvious and strident tone of fear ads will (further) lose their persuasive power. Young adults who have grown up with, and are perhaps the most appreciative of, postmodern advertising styles seem to respond to fear ads in what might be termed postmodern ways. For example, posters stating "Heroin screws you up" (a hard-hitting U.K. antidrugs campaign) were stolen by teenagers to decorate their bedroom walls (Hastings \& MacFadyen, 2002). Similarly, ironically branded Death cigarettes flourished in the 1990s: "Advertising-literate young people (could) de-code the warning . . . and it [the Death brand] quickly established a cult youth following" (Hatfield, 1994).

\section{CONCLUSIONS}

Despite evidence that fear messages are persuasive, marketers in both the commercial and social sectors should exercise caution over their use. The case for using fear appeals may be tentatively proven in the laboratory, but, in the real world, marketing questions about the use of fear remain unanswered (and often unexplored). There is a compelling need to examine the effects of fear messages on real consumers, in natural settings. These effects should include more than narrowly defined persuasiveness, and cover the full panoply of marketing implications. Strategic concerns, such as long-term effects and the impact on relationships, are important, along with the need to assess the relative effectiveness of fear approaches in all these areas compared with other creative approaches that have no or fewer harmful side effects.

There are also ethical questions about the employment of fear appeals. Ethical theory and practitioner codes of conduct suggest that there are potential dangers in using fear appeals. Most significantly, there is evidence that fear messages may encourage maladaptive threat-avoidance behaviors that may, in themselves, be damaging to health. There is also evidence that fear messages may be least effective with those who have low self-efficacy, thereby increasing health inequity across the population.

The authors call on marketers-and especially social marketers-to reexamine their fondness for fear appeals. There are genuine concerns about the broader marketing implications of fear appeals, and they may 
breach the Hippocratic injunction of "First, do no harm." These concerns need full and thorough investigation.

\section{REFERENCES}

Ajzen, I. (1988). Attitudes, personality and behavior. London: Open University Press.

Alwitt, L. F. (2002). Suspense and advertising responses. Journal of Consumer Psychology, 12, 35-49.

Anderson, R. B. (2000). Vicarious and persuasive influences on efficacy expectations and intentions to perform breast self-examination. Public Relations Review, 26, 97-114.

Arblaster, L. (1996). A review of the effectiveness of health promotion interventions aimed at reducing inequalities in health. London: Health Education Authority Report.

Arthur, D., \& Quester, P. (2003). The ethicality of using fear for social advertising. Australasian Marketing Journal, 11, 12-27.

Austin, E. W., Pinkleton, B., \& Fujioka, Y. (1999). Assessing prosocial message effectiveness: Effects of message quality, production quality, and persuasiveness. Journal of Health Communication, 4, 195-210.

Backer, T. E., Rogers, E. M., \& Sopory, P. (1992). Designing health communication campaigns: What works? Newbury Park, CA: Sage.

Baker, C. (1995). Advertising Works 8: Papers from the IPA Advertising Effectiveness Awards 1994. In Health Education Board for ScotlandSmoking: sticks and carrots (Chap. 18). Henley-on-Thames, England: NTC Publications.

Baron, R., Logan, H., Lilly, J., Inman, M., \& Brennan, M. (1994). Negative emotion and message processing. Journal of Experimental Social Psychology, 30, 181-201.

Barton, D. (1999). It takes two to make a relationship. Brandweek, 40, 14-15.

Batty, D. (2001, 15 June). Charity pulls suicide ad. The Guardian.

BBC News Online. (1998, November 2). UK morgue poster slated by pensioners. Available: http://news.bbc.co.uk/1/hi/uk/206098.stm

BBC News Online. (2000, January 21). Shockvertising: Ads that divide. Available: http://news.bbc.co.uk/1/hi/special_report/1999/02/99/e-cycolopedia/611979.stm

Beauchamp, T. L. (1988). Manipulative advertising. In T. L. Beauchamp \& N. E. Bowie (Eds.), Ethical theory and business (3rd ed.). Englewood Cliffs, NJ: Prentice-Hall.

Beauchamp, T. L., \& Bowie, N. E. (1988). Ethical theory and business (3rd ed.). Englewood Cliffs, NJ: Prentice-Hall.

Belch, G. E., \& Belch, M. A. (2001). Advertising and promotion: An integrated marketing communications perspective (5th ed.). New York: McGraw-Hill.

Belch, G. E., Belch, M. A., \& Jones, M. A. (1995). An exploratory investigation of teenagers' attitudes toward anti-drug appeals. European Advances in Consumer Research, 2, 329-336.

Belinoff, R. (1995). Branding: Confessions of a social marketing man. Social Marketing Quarterly, 2, 46-47. 
Benet, S., Pitts, R. E., \& LaTour, M. (1993). The appropriateness of fear appeal use for health-care marketing to the elderly-Is it OK to scare granny? Journal of Business Ethics, 12, 45-55.

Biel, A. L. (1998). Likeability: Why advertising that is well liked sells well. In J. P. Jones (Ed.), How advertising works: The role of research (Chap. 10). Thousand Oaks, CA: Sage.

Biener, L., McCallum-Keller, G., \& Nyman, A. L. (2000). Adults' response to Massachusetts anti-tobacco television advertisements: Impact of viewer and advertisement characteristics. Tobacco Control, 9, 401-407.

Biener, L., \& Taylor, T. M. (2002). The continuing importance of emotion in tobacco control media campaigns: A response to Hastings and MacFadyen. Tobacco Control, 11, 75-77.

Blumberg, S. J. (2000). Guarding against threatening HIV prevention messages: An information-processing model. Health Education and Behavior, 27, 780-795.

Bolling, J. H. (2001). From sunup to sundown: A patient-centric approach to pharmaceutical marketing. Pharmaceutical Executive, 21, 78-82.

Boster, F. J., \& Mongeau, P. (1984). Fear-arousing persuasive messages. Communication Yearbook, 8, 330-375.

Botvin, G. J., Malgady, R. G., Griffin, K. W., Sheier, L. M., \& Epstein, J. A. (1998). Alcohol and marijuana use among rural youth: Interaction of social and intrapersonal influences. Addictive Behavior, 23, 379-387.

Brody, A. (1998). Why the Massachusetts anti-cigarette campaign won't work [Online]. Available: http://www.tobacco.org/News/9810brody.html

Brown, S. P., Homer, P. M., \& Inman, J. J. (1998). A meta-analysis of relationships between ad-evoked feelings and advertising responses. Journal of Marketing Research, 35, 114-126.

Buchanan, D. R., \& Wallack, L. (1998). This is the partnership for a drug-free America. Any questions? Journal of Drug Issues, 28, 329-356.

Bureau NDM. (2001). Annual report. Utrecht, the Netherlands: National Drugs Monitor.

Chapman, S. (1999). Scare tactics cut smoking rates in Australia to all time low. British Medical Journal, 318, 1508.

Chaudhuri, A. (1996). The effect of media, product and message factors on ad persuasiveness: The role of affect and cognition. Journal of Marketing Communications, 2, 201-218.

Cohn, J. (1998, August 5). Don't just say no-Berkeley researcher Dr. Joel Brown questions effectiveness of the federal government's antidrug education program. San Franscisco Bay Guardian [On-line]. Available: http://www.cerd.org/ press/press03.html

Conrad, K. M., Flay, B. R., \& Hill, D. (1992). Why children start smoking cigarettes: Predictors of onset. British Journal of Addiction, 87, 1711-1724.

Cotroneo, S., \& Schoales, T. (1999). Quit4Life: A Health Canada Tobacco Cessation Program. Proceedings of the Fifth Annual Innovations in Social Marketing Conference, Montreal, Canada, 18-20 July.

Coulter, R. H., Cotte, J., \& Moore, M. L. (1999). Believe it or not: Persuasion, manipulation and credibility of guilt appeals. Advances in Consumer Research, 26, 288-294.

de Chernatony, L. (2001). From brand vision to brand evaluation. Oxford: Butterworth-Heinemann. 
DeJong, W., \& Hoffman, K. D. (2000). A content analysis of television advertising for the Massachusetts Tobacco Control Program media campaign, 1993-1996. Journal of Public Health Management and Practice, 6, 40-44.

DeJong, W., \& Wallack, L. (1999). A critical perspective on the drug czar's antidrug media campaign. Journal of Health Communication, 4, 155-160.

de Turck, M. A., Goldhaber, G. M., Richetto, G. M., \& Young, M. J. (1992). Effects of fear-arousing warning messages. Journal of Products Liability, 14, 217-223.

de Turck, M. A., Rachlin, R. A., \& Young, M. J. (1994). Effects of a role model and fear in warning label on perceptions of safety and safety behavior. Advances in Consumer Research, 21, 208-212.

Devlin, E., Eadie, D., Hastings, G., \& Anderson, S. (2002, September). Labelling of tobacco products in Europe: Results from the U.K. report prepared for the European Commission. Glasgow, Scotland: University of Strathclyde, Cancer Research UK Centre for Tobacco Control Research.

Donovan, R. J. (1991). Public health advertising: Guidelines for health promotion professionals. Health Promotion Journal of Australia, 1, 40-45.

Donovan, R. J., \& Henley, N. (1997). Negative outcomes, threats and threat appeals: Widening the conceptual framework for the study of fear and other emotions in social marketing communications. Social Marketing Quarterly, 4, $56-67$.

Donovan, R. J., Jalleh, G., \& Henley, N. (1999). Executing effective road safety advertising: Are big production budgets necessary? Accident Analysis \& Prevention, 31, 243-252.

Doyle, P. (1989). Building successful brands: The strategic options. Journal of Marketing Management, 5, 77-95.

Doyle, P. (1997, January 18). The Guardian.

Duke, C. R., Pickett, L. C., \& Grove, S. J. (1993). A method for evaluating the ethics of fear appeals. Journal of Public Policy \& Marketing, 1, 120-129.

Eadie, D. R., \& Smith, C. J. (1995). Communicating about cancers: Formative research to guide the strategic development of a mass media cancer campaign. Final report. Glasgow, Scotland: Centre for Social Marketing.

Eadie, D. R., \& Stead, M. (1998, December). Developing the Foolsspeed 40" commercial-Main findings. Glasgow: University of Strathclyde, Centre for Social Marketing.

Elders, M. J., Perry, C. L., Eriksen, M. P., \& Giovino, G. A. (1994). The report of the Surgeon General: Preventing tobacco use among young people. American Journal of Public Health, 84, 543-547.

Fry, T. R. (1996). Advertising wearout in the Transport Accident Commission road safety campaigns. Accident Analysis \& Prevention, 28, 123-129.

Girandola, F. (2000). Fear and persuasion: Review and re-analysis of the literature (1953-1998). Année Psychologique, 100, 2, 333-376.

Goldman, L. K., \& Glantz, S. A. (1998). Evaluation of antismoking advertising campaigns. Journal of the American Medical Association, 279, 772-777.

Goodman, J. A. (1995, June). Building a world-class service system and setting rational priorities. Arlington, VA: Technical Assistance Research Programs, Inc.

Grey, A., Owen, L., \& Bolling, K (2000). A breath of fresh air: Tackling smoking through the media. London: Health Development Agency.

Grönroos, C. (1994). From marketing mix to relationship marketing: Towards a paradigm shift in marketing. Management Decisions, 32, 4-20. 
Grönroos, C. (1995). Relationship marketing: The strategy continuum. Journal of the Academy of Marketing Science, 23, 252-254.

Hackley, C. E., \& Kitchen, P. J. (1999). Ethical perspectives on the postmodern communications Leviathan. Journal of Business Ethics, 20, 15-26.

Hale, J., \& Dillard, J. P. (1995). Fear appeals in health promotion campaigns. In E. Maibach \& R. L. Parrott (Eds.), Designing health messages. Thousand Oaks, CA: Sage.

Hastings, G. B. (2003). Relational paradigms in social marketing. Journal of Macromarketing, 23, 6-15.

Hastings, G. B., Eadie, D. R., \& Scott, A. C. (1990). Two years of AIDS publicity: A review of progress in Scotland. Health Education Research, 5, 17-25.

Hastings, G. B., Leather, D. S., \& Scott, A. C. (1987). AIDS publicity: Some experiences from Scotland. British Medical Journal, 294, 48-49.

Hastings, G. B., \& MacFadyen, L. (2002). The limitations of fear messages. Tobacco Control, 11, 73-75.

Hastings, G. B., Stead, M., Whitehead, M., Lowry, R., MacFadyen, L., McVey, D., Owen, L., \& Tones, K. (1998). Using the media to tackle the health divide: Future directions. Social Marketing Quarterly, 4, 42-67.

Hatfield, S. (1994, March 31). Perspective: When "honesty" in ads becomes just another gimmick. Campaign.

Health Education Board of Scotland (HEBS). (2001). Annual report 2000/2001. Edinburgh, Scotland: Health Education Board for Scotland.

Health Education Board of Scotland. (2002). HEBS club smoking open its doors [On-line]. Available: http://www.hebs.scot.nhs.uk/info/press/pressection.cfm? TxtTCode $=1258 \&$ TA

Henley, N. (2002). You will die!: Mass media invocations of existential dread. M/C: A Journal of Media and Culture [On-line], 5, 1. Available: http://www. media-culture.org.au/0203/youwilldie.html

Henthorne, T. L., LaTour, M. S., \& Nataraajan, R. (1993). Fear appeals in print advertising-An analysis of arousal and ad response. Journal of Advertising, 22, 59-69.

Hevey, D. (1992). Fear for sale. New Internationalist, 233.

Higbee, K. L. (1969). Fifteen years of fear arousal: Research on threat appeals. Psychological Bulletin, 72, 426-444.

Hill, D., Chapman, S., \& Donovan, R. (1998). The return of scare tactics. Tobacco Control, 7, 5-8.

Hyman, M. R., \& Tansey, R. (1990). The ethics of psychoactive ads. Journal of Business Ethics, 9, 105-114.

Janis, I. L. (1967). Effects of fear arousal on attitude change: Recent developments in theory and experimental research. In L. Berkowitz (Ed.), Advances in experimental social psychology (Vol. 3). New York: Academic Press.

Janis, I. L., \& Mann, L. (1997). Decision making: A psychological analysis of conflict, choice and commitment. New York: The Free Press.

Japerson, A. E., \& Fan, D. P. (2002). An aggregate examination of the backlash effect in political advertising: The case of the 1996 U.S. Senate race in Minnesota. Journal of Advertising, 31, 1-12.

Johar, J. S., \& Segal, M. N. (1987). Exploratory assessment of the effect of alternative advertising appeals. Advances in Consumer Research, 14, 527. 
Johnson, C. A., Pentz, M. A., Weber, M. D., Dwyer, J. H., Baer, N., MacKinnon, D. P., \& Hansen, W. B. (1990). Relative effectiveness of comprehensive community programming for drug abuse prevention with high risk and low risk adolescents. Journal of Consulting and Clinical Psychology, 58, 447-456.

Keller, K. L. (1998). Branding perspectives on social marketing. Advances in Consumer Research, 25, 299-302.

Keller, P. A. (1999). Converting the unconverted: The effect of inclination and opportunity to discount health-related fear appeals. Journal of Applied Psychology, 84, 403-415.

Keller, P. A., \& Block, L. G. (1996). Increasing the persuasiveness of fear appeals: The effect of arousal and elaboration. Journal of Consumer Research, 22, 448-459.

Kirmani, A. (1997). Advertising repetition as a signal of quality: If it's advertised so much something must be wrong. Journal of Advertising, 26, 77-86.

Kitchen, P. J. (1986). Zipping, zapping and nipping. International Journal of Advertising, 5, 343-352.

Knauer, V. (1992). Increasing customer satisfaction. Pueblo, CO: U.S. Office of Consumer Affairs.

Krisher, H., Darley, S., \& Darley, J. M. (1973). Fear provoking recommendations, intentions to take preventive actions, and actual preventive action. Journal of Personality and Social Psychology, 26, 301-308.

Land Transport Safety Authority. (2001). LTSA advertising campaigns [Online]. New Zealand: Wellington. Source: http://www.ltsa.govt.nz/studyguides/advertising.html.

Lannon, J., \& Cooper, P. (1983). Humanistic advertising: A holistic cultural perspective. International Journal of Advertising, 2, 195-213.

Laroche, M., Toffoli, R., Zhang, Q., \& Pons, F. (2001). A cross-cultural study of the persuasive effect of fear appeal messages in cigarette advertising: China and Canada. International Journal of Advertising, 20, 3-11.

LaTour, M. S., \& Pitts, R. E. (1989). Using fear appeals for AIDS prevention in college aged population: An analysis of arousal and ad response. Journal of Healthcare Marketing, 9, 5-14.

LaTour, M. S., \& Rotfeld, H. J. (1997). There are threats and (maybe) fear-caused arousal: Theory and confusions of appeals to fear and fear arousal itself. Journal of Advertising, 26, 45-59.

LaTour, M. S., Snipes, R. L., \& Bliss, S. J. (1996). Don't be afraid to use fear appeals: An experimental study. Journal of Advertising Research, 36, 59-67.

LaTour, M., \& Zahra, S. (1989). Fear appeals as advertising strategy: Should they be used? Journal of Consumer Marketing, 6, 61-70.

Leventhal, H. (1970). Findings and theory in the study of fear communications. Advances in Experimental Social Psychology, 5, 119-187.

MacAskill, S. G., \& Eadie, D. R. (1995). The Scottish Office Home and Health Department domestic violence media campaign-Part 1: Qualitative evaluation. Glasgow, Scotland: University of Strathclyde, Centre for Social Marketing.

MacAskill, S., Will, V., Hughes, K., \& Eadie, D. (1993). The Health Education Board for Scotland's 1992 anti-smoking initiative. Glasgow, Scotland: University of Strathclyde, Centre for Social Marketing. 
Macpherson, T., \& Lewis, T. (1998). New Zealand drink-driving statistics: The effectiveness of road safety television advertising. Marketing Bulletin, 9, 40-51.

Mayne, T. J. (1999). Negative affect and health: The importance of being earnest. Cognition and Emotion, 13, 601-635.

Meirick, P. (2002). Cognitive responses to negative and comparative political advertising. Journal of Advertising, 31, 49-59.

Menasco, M., \& Baron, P. (1982). Threats and promises in advertising appeals. Advances in Consumer Research, 9, 221-227.

Millar, M. G., \& Miller, K. (1998). Processing messages about disease detection and health promotion behaviors: The effects of anxiety. Health Communication, 10, 211-226.

Monahan, J. L. (1995). Thinking positively: Using positive affect when designing health messages. In E. Maibach \& R. L. Parrott (Eds.), Designing health messages (Chap. 5). Thousand Oaks, CA: Sage.

Moore, D. J., \& Harris, W. D. (1996). Affect intensity and the consumer's attitude toward high impact emotional advertising appeals. Journal of Advertising, 25, 37-50.

Moore, D. J., \& Hoenig, S. (1989). Negative emotions as mediators of attitudes in advertising appeals. Advances in Consumer Research, 16, 581-586.

Morgan, R. M., \& Hunt, S. D. (1994). The commitment-trust theory of relationship marketing. Journal of Marketing, 58, 20-38.

O'Driscoll, A., \& Murray, J.A. (1998). The changing nature of theory and practice in marketing: On the value of synchrony. Journal of Marketing Management, 14, 391-416.

O’Malley, L. (1998). Can loyalty schemes really build loyalty? Marketing Intelligence \& Planning, 6, 47-56.

O'Malley, L., \& Tynan, C. (2000). Relationship marketing in consumer markets: Rhetoric or reality? European Journal of Marketing, 34, 797-815.

Ong, G., Austoker, J., \& Brouwer, A. (1996). Evaluation of the written information sent to women who are called back for further investigation of breast screening in the UK. Health Education Journal, 55, 413-429.

PBS Newshour. (1999, August 2). Air campaign. Available: http://www.pbs.org/ newshour/bb/media/july-dec99/drugs_8-2.html

Pechmann, C. (2001). Changing adolescent smoking prevalence: Impact of advertising interventions. The National Cancer Insitute, Smoking and Tobacco Control Monograph No. 14 [On-line]. Available: http://cancercontrol.cancer.gov/tcrb/monographs

Pelsmacker, P. D. E., \& Geuens, M. (1999). The advertising effectiveness of different levels of intensity of humour and warmth and the moderating role of top of mind awareness and degree of product use. Journal of Marketing Communications, 5, 113-129.

Pierce, J. P., Macaskill, P., \& Hill, D. (1998). Long-term effectiveness of mass media led anti-smoking campaigns in Australia. American Journal of Public Health, 80, 565-569.

Pinkleton, B., Um, N.-H., \& Austin, E. W. (2002). An exploration of the effects of negative political advertising on political decision making. Journal of Advertising, 31, 13-25.

Quinn, V., Meenaghan, A., \& Brannick, T. (1992). Fear appeals: Segmentation is the way to go. International Journal of Advertising, 11, 355-366. 
Ramrayka, L. (2001, June 15). Charities struggle to find right balance with ad campaigns. The Guardian.

Rayner, J. (1999, August 8). Why this NSPCC advert is harmful to children. The Observer.

Reicheld, F. F., \& Sasser, W. E. J. (1990, September/October). Zero defections: Quality comes to services. Harvard Business Review, p. 105-111.

Reichert, T., Heckler, S. E., \& Jackson, S. (2001). The effects of sexual social marketing appeals on cognitive processing and persuasion. Journal of Advertising, 30, 13-27.

Richardson, F. (2001). Packages: The money or the options. Business Review Weekly [On-line], 23, 20. Available: http://www.brw.com.au

Rippetoe, P. A., \& Rogers, R. W. (1987). Effects of components of protection-motivation theory on adaptive and maladaptive coping with a health threat. Journal of Personality and Social Psychology, 52, 596-604.

Rogers, R. W. (1983). Cognitive and physiological processes in fear appeals and attitude change: A revised theory of protection motivation. In J. Cacioppo \& R. Petty (Eds.), Social psychophysiology. New York: Guilford Press.

Rossiter, J. R., \& Eagleson, G. (1994). Conclusions from the ARF's copy research validity project. Journal of Advertising Research, 34, 19-32.

Rotfeld, H. (1988). Fear appeals and persuasion: Assumption and errors in advertising research. Current Issues \& Research in Advertising, 11, 21-40.

Ruiter, R. A. C., Abraham, C., \& Kok, G. (2001). Scary warnings and rational precautions: A review of the psychology of fear appeals. Psychology \& Health, $16,613-630$.

Schoales, T., Mintz, J., \& Hazel, J (1999). Challenge to youth: A Health Canada anti-tobacco campaign. Proceedings of the fifth annual innovations in social marketing conference, Montreal, Canada, July 18-20.

Schoenbachler, D. D., \& Whittler, T. E. (1996). Adolescent processing of social and physical threat communications. Journal of Advertising, 25, 37-54.

Sego, T., \& Stout, P. (1994). Anxiety associated with social issues: The development of a scale to measure an antecedent construct. Advances in Consumer Research, 21, 601-606.

Slater, M. D. (1999). Drinking and driving PSAs: A content analysis of behavioral influence strategies. Journal of Alcohol and Drug Education, 44, 68-81.

Smith, N. C., \& Quelch, J. A. (1992). Ethical issues in researching and targeting consumers. In N. C. Smith \& J. A. Quelch (Eds.), Ethics in marketing. Boston: Irwin.

Smith, S. L. (1997). The effective use of fear appeals in persuasive immunization: An analysis of national immunization intervention messages. Journal of Applied Communication Research, 25, 264-292.

Snipes, R. L., LaTour, M. S., \& Bliss, S. J. (1999). A model of the effects of selfefficacy on the perceived ethicality and performance of fear appeals in advertising. Journal of Business Ethics, 19, 273-285.

Stead, M., \& Eadie, D. R. (2000, January). Developing the Foolsspeed phase 2 commercial-Main findings. Glasgow, Scotland: University of Strathclyde, Centre for Social Marketing.

Stead, M., \& Eadie, D. R. (2001, January). Developing the Foolsspeed phase 3 campaign-Main findings. Glasgow, Scotland: University of Strathclyde, Centre for Social Marketing.

Stead, M., Low, E., \& MacFadyen, L. (1996, November). Research to assist the development of the new cervical screening protocol for Newcastle and North 
Tyneside Health Authority: Pretest of invitation and results letters. Research report. Glasgow, Scotland: University of Strathclyde, Centre for Social Marketing.

Stivoro (1998). Tobacco control in the Netherlands. Available: http://www.stivoro.nl/algemeen/publicat/english/tobcontr.htm

Tanner, J. F. Jr., Hunt, J. B., \& Eppright, D. R. (1991). The protection motivation model: A normative model of fear appeals. Journal of Marketing, 55, 36-45.

Transport Accident Commission. (2002). The TAC's road safety campaign. Victoria, Australia.

Treasure, J. (2002, May 23). A relationship's success relies on conversation. Marketing, 22.

Tripp, G., \& Davenport, A. (1988/89). Fear advertising-It doesn't work! Health Canada Online. Available: http://www.hc-sc.gc.ca/hppb/socialmarketing/ resources/somarhpe/smhp12e.htm

Tynan, C. (1997). A review of the marriage analogy in relationship marketing. Journal of Marketing Management, 13, 695-703.

Tzokas, N, \& Saren, M. J. (1997). Some dangerous axioms of relationship marketing. Journal of Strategic Marketing, 6, 187-196.

Wan, F., Meirick, P., Williams, J., Holmes, J., \& Feibich, C. (2000). Threat, authoritarianism and political advertising: An experiment in personality and persuasion[On-line]. Paper presented at the Association for Education in Journalism and Mass Communication (AEJMC) Conference, Advertising Division, Phoenix, AZ. Available: http://www.aejmc.org

Weinreich, L. (1999). 11 steps to brand heaven. London, England: Kogan Page.

Weir, L., \& Hibbert, S. (2000). Building donor relationships: An investigation into the use of relationship and database marketing by charity fundraisers. The Service Industries Journal, 20, 114-132.

Wertz, S. (1998). Significance of emotion. Available: http://www. ciadvertising.org/studies/student/98_fall/theory/weirtz/Significance.htm

Williams, J. D., Briley, D. A., Grier, S., \& Henderson, G. (1998). A cross-cultural examination of fear-appeal advertising in an individualism-collectivism framework. Asia Pacific Advances in Consumer Research, 3, 26-29.

Witte, K., \& Allen, M. (2000). A meta-analysis of fear appeals: Implications for effective public health campaigns. Health Education \& Behavior, 27, 591-615.

Witte, K., Berkowitz, J. M., Cameron, K. A., \& McKeon, J. K. (1998). Preventing the spread of genital warts: Using fear appeals to promote self-protective behaviors. Health Education \& Behavior, 25, 571-585.

Correspondence regarding this article should be sent to: Gerard Hastings, c/o Professor Andrew McAuley, Centre for Social Marketing, University of Stirling Department of Marketing and Open University Business School, Stirling FK9 4LA, Scotland, UK (marketing@stir.ac.uk). 